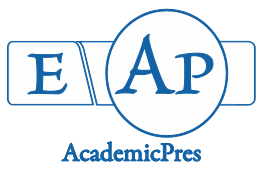

Kanta C and Sharma IP (2020)

Notulae Scientia Biologicae 12(2):289-300

DOI: $10.15835 / \mathrm{nsb} 12210722$

Research Article

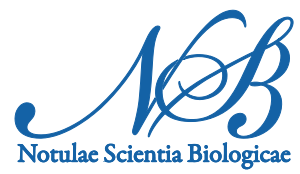

\title{
Floral polymorphism and scanning electron microscopy determination in relation to climatic influence on Solanum nigrum $\mathrm{L}$.
}

\author{
Chandra KANTA ${ }^{1,2}$, Ishwar P. SHARMA ${ }^{2 *}$ \\ ${ }^{1}$ Doon (PG) College of Agriculture, Sciences and Technology, Department of Botany, Dehradun 248 197, Uttarakhand, \\ India; ck.pathak116@gmail.com \\ ${ }^{2}$ G.B. Pant University of Agriculture and Technology, Department of Biological Sciences, College of Basic Sciences and Humanities, \\ Pantnagar 263 145, U.S. Nagar, Uttarakhand, India; ipsharma.com@gmail.com (*corresponding author)
}

\begin{abstract}
Growing concern about climatic influence on plants reproductive biology leads to a recent surge. Climate affects directly floral morphology of plants on this basis current study summarizes climatic effects on floral or reproductive biology of Solanum nigrum L. Effect of summer, rainy and winter seasons were recorded on floral morphology, pollens viability \& germination, pollen tube growth, fruit-set percentage during investigations which were subjected to one factorial analysis of variance (ANOVA) and least significant differences at $\mathrm{p}<0.05$. Climatic conditions affect floral morphology and produce polymorphism in specific conditions. In rainy and winter seasons, polymorphism was recorded in petals, stamens and pistil which is a first record of climatic influence on polymorphism. Rainy season reported for their maximum flowers numbers which promote a huge fruit-set percentage in open pollination as compared with self and cross pollination. This study confirms the effect of various climates on different floral parts which produce polymorphism along with growth, germination, length, etc. Scanning Electron Microscopy (SEM) study indicated the climatic variations on microscopic observations.
\end{abstract}

Keywords: climate; floral biology; pollen; polymorphism; Solanum nigrum L.

\section{Introduction}

Climate change affects the diversity of all living things through a variety of ways (Hughes, 2000; Walther et al., 2002; Parmesan, 2006). Commonly, climate change mainly warming is leading the shift in timing of life history events for many species (Parmesan and Yohe, 2003; Root et al., 2003) and it also affects reproductive success of organism (Sedgley and Griffin, 1889). Many individuals who can adapt to their current climatic conditions but due to change in climate their passed genes to next generation not well adapted (Shivanna, 2003). The process by which the climate-organism interaction is translated into changes in underlying genetic structure of population is natural selection (Raghavan, 2000; Dutkuner et al., 2008). The physiology of reproduction in most flowering plants is markedly influenced by environmental factors (Taiz and Zeiger, 2003) which are generally influence the characters, composition, growth and development of individual plants and plant communities (Lawlor, 2002). In plant reproductive systems, environment exerts considerable influence 
on flowering, pollen fertility, pollen germination and fruiting (Shivanna and Johri, 1985; Shivanna, 2003). Perennial trees interact with environment all-round the year while there flowering and fruiting are closely related to seasonal climatic changes (Sedgley and Griffin, 1989). Extensive studies have been made on the effect of various environmental factors on floral development, pollen fertility, female sterility, flower and fruit abscission including diseases on the development of fruit in plants (Shivanna, 2003). The selected plant, Solanum nigrum L. is an annual herb, belonging to family Solanaceae and native of Eurasia (Ogg and Rogers, 1989). It is generally found in disturbed habitats such as roadsides, often on arable land especially, the edges of cultivated fields and plantation and in areas around building and garden; grow well in high nitrogen or phosphorus containing soils (Holm et al., 1977). Medicinally this is most important plant and used in hepatitis $B$ virus infection, cardiovascular stimulant, diuretic, anti-inflammatory, anti-oxidative, immunomodulation properties and lowering blood pressure due to breakdown of cholesterol (De Silva et al., 2003; Fallah et al., 2005). Despite of its high economic and medicinal value limited information is available on its reproductive biology. However, the floral and reproductive biology of Solanum nigrum L. has not been studied; hence, present study assesses the extent of climatic conditions in based on floral biology.

\section{Materials and Methods}

Solanum nigrum $\mathrm{L}$. selected as an experimental plant which was grown naturally and evaluated for floral characteristics in three selected seasons; rainy, winter and summer. The metrological data for various seasons were collected from concern metrological department. At the time of flower initiation randomly inflorescences were selected and tagged than number of open flowers recorded daily. Floral morphology, number of pollen grains and ovules were studied by the methods of Kearns and Inouye (Kearns and Inouye, 1993). Anthesis, anther dehiscence and stigma receptivity were recorded by the methods of Shivanna and Rangaswamy (1992). Total number of pollens per anther and per flower was measured by using hemocytometer (Barret, 1985). Pollen viability was assessed by fluorescence - FCR and $1 \%$ TTC (2, 3, 5-triphenyltetrazolium chloride) method (Shivanna and Rangaswamy, 1992). In vitro pollen germination was checked by hanging drop culture method (Brewbaker and Kwack, 1963) and in different concentration of sucrose solutions (10\%, 20\% and 30\%). In vivo pollen germination was checked by Alexander's and aniline blue fluorescence microscopic method (Shivanna and Rangaswamy, 1992). The morphology of different floral parts was studied by Scanning Electron Microscopy (SEM) from LEO-EM-SEM at All India Institute of Medical Sciences (AIIMS), New Delhi. Fruit development was observed from day of pollination to maturation and dehiscence. Mature fruits from plants were harvested and collected both fruits and were collected. Fruit-set and seed-set percentage was calculated by the following formula-

$$
\begin{gathered}
\text { Fruit }- \text { set } \%=\frac{\text { No. of fruits } / \text { Inflorescence }}{\text { No. of flowers/Inflorescence }} \times 100 \\
\text { Seed }- \text { set } \%=\frac{\text { No. of seed/Fruit }}{\text { No. of ovules/Pistil }} \times 100
\end{gathered}
$$

For pollination mechanism under selected climatic conditions pollinators, their population, visitation rate and pollination efficiency of different pollinators were recorded by observing pollen load under microscope (Kearns and Inouye, 1993). Breeding behaviors (autogamy, geitenogamy and xenogamy) was tested using control pollination studies in emasculated and bagged flowers (Shivanna and Rangaswamy, 1992).

Statistically, data were presented in mean values \pm SD with ten replicates $(n=10)$, one factorial analysis of variance (ANOVA) and least significant differences at $\mathrm{p}<0.05$. 


\section{Results}

In results, direct effect of climate was observed on vegetative and various floral parts of Solanum nigrum L. The observed taxonomic characteristics of plant expressed in Table 1, Figures 1 and 2. The most valuable variations in floral characters during different season were number of flowers, time taken for anthesis, dehiscence and stigma receptivity. Maximum numbers of flowers (7.42) were recorded during rainy season followed by winter (6.43) and summer (5.95); in the case of anthesis at least time (800-830 h) recorded in rainy season while maximum in winter; for the time of anther dehiscence and stigma receptivity, summer and rainy seasons performed similar time (830-900 h) (Table 2). Flower parts mainly petals, stamens, and pistils showed polymorphism during this investigation; main influence on these parts were affected by winter and rainy season; during winter the flower parts increased in their number and size while petals number and size decreased by rainy climate, rest of the investigation flowers performed without polymorphism (Table 3, Figure 3). Scanning electron macroscopy (SEM) of flower (Figure 4), stamen (Figure 5) and pistillate part (Figure 6) clearly shows various patterns of trichomes, necteries, pores, pollen grains etc. in their respective ways.

Table 1. Observations of various common floral characters

\begin{tabular}{|c|c|}
\hline Floral Characters & Observations \\
\hline Type of inflorescence & Extra-axillary scorpioid cyme \\
\hline Floral architecture & Small, full open, complete, hermaphrodite \\
\hline Colour of flower & White \\
\hline Shape of flower & Star shaped \\
\hline Calyx & 5, green, bell shaped, gamosepalous, valvate, persistent \\
\hline Corolla & 5, white, gamopetalous, valvate, rotate \\
\hline Number of stamens & 5, polyandrous \\
\hline Mode of dehiscence & Apical pores \\
\hline Number of pistils & 1, short \\
\hline Stigma type & Bilobed, wet, papillate \\
\hline Style type & Short, white, cylindrical, hairy at base, solid \\
\hline Ovary type & Bicarpellary, syncarpous, superior, bilocular \\
\hline Pollen grain size & $30-45 \mu \mathrm{m}$ \\
\hline No. of pollen/anther & $700 \pm 11.9$ \\
\hline No. of pollen/flower & $3500 \pm 112.59$ \\
\hline No. of ovules/ovary & $48 \pm 1.32$ \\
\hline Pollen ovule ratio & $70: 1$ \\
\hline Fruit shape & Oval or Spherical \\
\hline Fruit colour & Unripe - green, ripe - red \\
\hline Fruit diameter $(\mathrm{mm})$ & $20 \pm 1.15$ \\
\hline Weight of dry fruit (mg) & $61 \pm 1.05$ \\
\hline Seeds per fruit & $35 \pm 3.07$ \\
\hline Seed colour & Whitish brown \\
\hline Seed shape & Small, flattened \\
\hline Seed size $(\mathrm{mm})$ & $2.04 \pm 0.106$ \\
\hline Weight of 100 seeds $(\mathrm{mg})$ & $250 \pm 2.19$ \\
\hline Seed-set & $83.33 \%$ \\
\hline
\end{tabular}




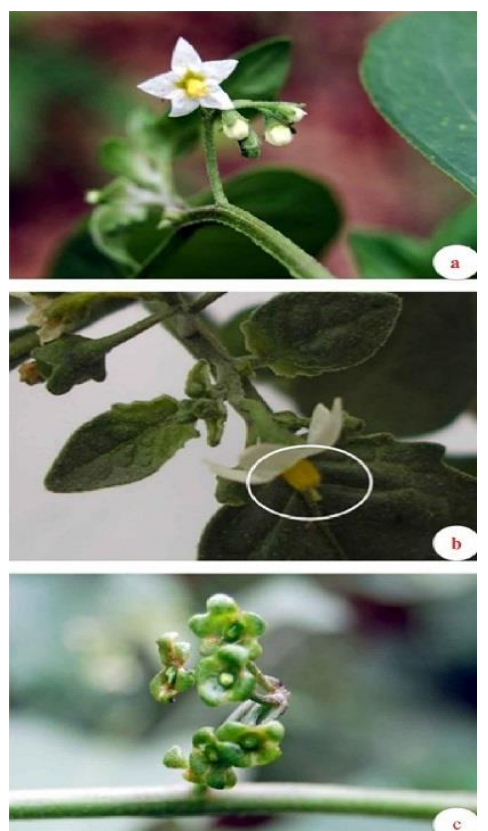

Figure 1. Floral biology of $S$. nigrum. a. extra axillary scorpioid cyme; b. anthers; c. persistent calyx
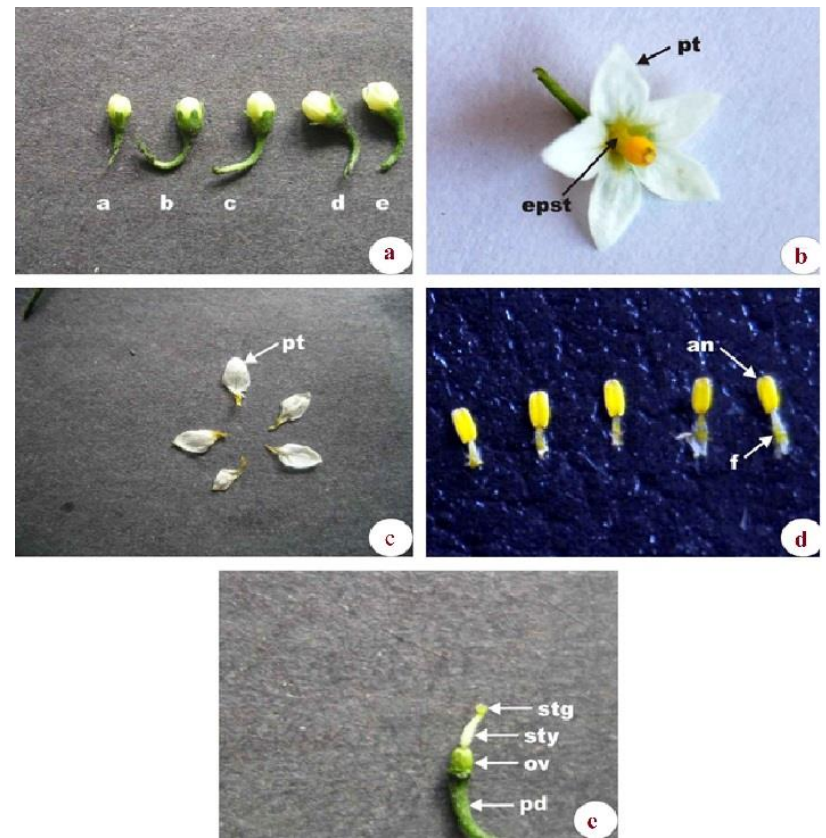

Figure 2. Flower development and arrangement of floral parts. a. stages of flower development; $\mathbf{b}$. epipepatalous (epst) condition; c. petals (pt); d. dithecous anther (an) with filament (f); e. different parts of pistil

Table 2. Variation in some floral characters under different season

\begin{tabular}{|c|c|c|c|}
\hline \multirow{2}{*}{ Floral characters } & \multicolumn{3}{|c|}{ Seasons } \\
\hline & Winter & Summer & Rainy \\
\hline Flower/inflorescence & $6.43 \pm 2.09$ & $5.95 \pm 0.04$ & $7.42 \pm 1.34$ \\
\hline Time of anthesis $(\mathrm{h})$ & 0930-1000 & 0830-0900 & 0800-0830 \\
\hline Time of anther dehiscence (h) & $0930-1000$ & $0830-0900$ & 0830-0900 \\
\hline Time of stigma receptivity $(\mathrm{h})$ & 0930-1000 & 0830-0900 & 0830-0900 \\
\hline
\end{tabular}


Table 3. Floral polymorphism in Solanum nigrum L. under different seasons

\begin{tabular}{|c|c|c|c|c|c|c|c|c|c|}
\hline \multirow{2}{*}{ Seasons } & \multirow{2}{*}{ Month } & \multicolumn{2}{|c|}{ Temp $\left({ }^{\circ} \mathrm{C}\right)$} & \multirow{2}{*}{$\begin{array}{c}\text { Humidity } \\
(\%)\end{array}$} & \multicolumn{3}{|c|}{ Numbers } & \multirow{2}{*}{$\begin{array}{c}\text { Petal's } \\
\text { length }(\mathrm{mm})\end{array}$} & \multirow{2}{*}{$\begin{array}{c}\text { Flowers } \\
(\%)\end{array}$} \\
\hline & & Max & Min & & Petal & Stamen & Pistil & & \\
\hline \multirow{4}{*}{ Winter } & Dec & 25.9 & 11.4 & 82 & \multicolumn{5}{|c|}{ No Polymorphism (NP) } \\
\hline & Jan & 21.4 & 7.6 & 81 & 10 & 10 & 2 & $9.44 \pm 4.96$ & 10 \\
\hline & Feb & 27.8 & 10.4 & 80 & 9 & 10 & 2 & $8.44 \pm 4.96$ & 15 \\
\hline & Mar & 31.2 & 17.0 & 79 & \multicolumn{5}{|c|}{ No Polymorphism (NP) } \\
\hline \multirow{3}{*}{ Summer } & April & 33.4 & 19.6 & 60 & \multicolumn{5}{|c|}{ No Polymorphism (NP) } \\
\hline & May & 38.0 & 27.0 & 57 & \multicolumn{5}{|c|}{ No Polymorphism (NP) } \\
\hline & June & 40.5 & 24.5 & 58 & \multicolumn{5}{|c|}{ No Polymorphism (NP) } \\
\hline \multirow{4}{*}{ Rainy } & July & 31.6 & 24.9 & 95 & \multicolumn{5}{|c|}{ No Polymorphism (NP) } \\
\hline & Aug. & 28.6 & 25.6 & 96 & 4 & NP & NP & $4.08 \pm 0.07$ & 40 \\
\hline & Sep. & 32.0 & 24.0 & 95 & 4 & NP & NP & $4.08 \pm 0.07$ & 40 \\
\hline & Oct & 33.2 & 18.5 & 88 & \multicolumn{5}{|c|}{ No Polymorphism (NP) } \\
\hline
\end{tabular}
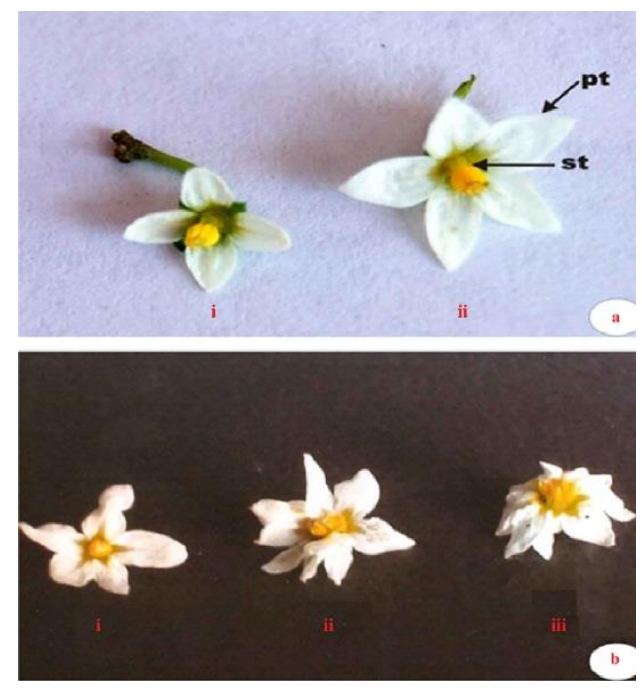

Figure 3. Floral polymorphism a. Flower with four (i) and five (ii) petals; b. flower with five large petals and five stamens (i), nine petals, ten stamens and two pistils (ii), ten petals, ten stamens and two pistils (iii)
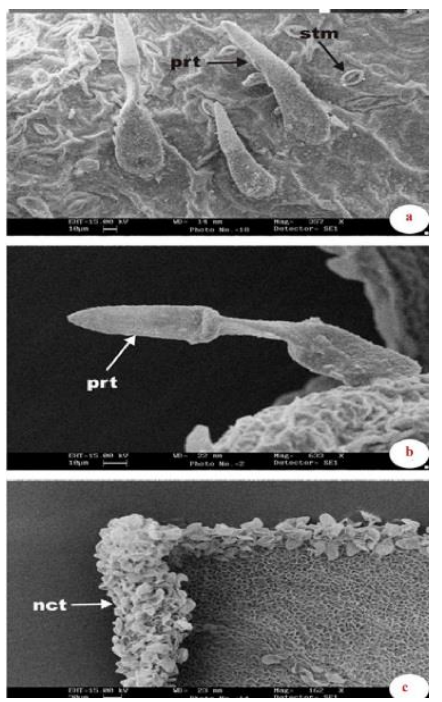

Figure 4. Trichomes on various floral parts a. stomata (stm) and procumbent type of trichome (prt) on dorsal surface of sepal 357X; b. magnified view of procumbent trichomes (prt) 633X; c. nacteries (nct) on upper portion of petal $162 \mathrm{X}$ 

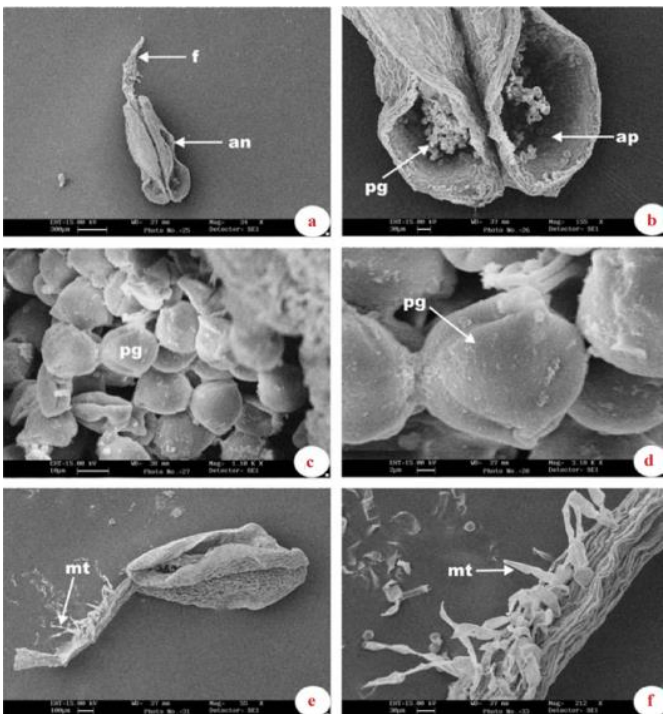

Figure 5. Scanning electron photomicrographs of staminate parts a. dithecous condition 34X; b. dehiscence through apical pore (ap) and anther lobe with pollen grain (pg) 155X; c. tricolporate pollen grain with reticulate exine sculpturing $1.10 \mathrm{KX}$; d. magnified view of pollen grain (pg) $3.18 \mathrm{KX}$; e. filaments showing multicellular trichome $(\mathrm{mt}) 55 \mathrm{X}$; f. magnified view of multicellular trichome $212 \mathrm{X}$

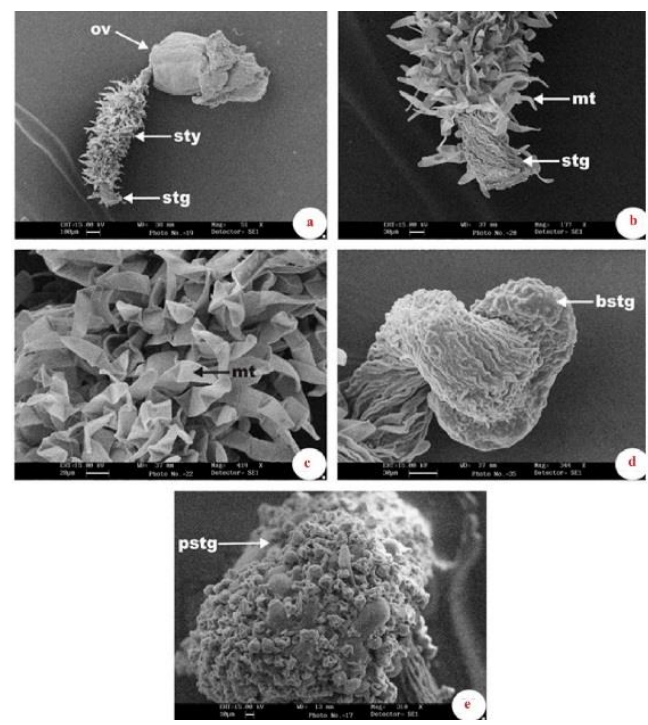

Figure 6. Scanning electron photomicrographs of pistillate parts a. pistil 51X; b. multicellular trichome $(\mathrm{mt})$ on stylar surface 177X; c. magnified view of multicellular trichomes (mt) 419X; d. bilobed stigma (bstg) 344X; e. compact arranged papillae on stigmatic surface $310 \mathrm{X}$

In respect with various climatic conditions maximum pollen viability was recorded during rainy season followed by winter in all the selected tests. Alexander test performed much better in all the seasons; during rainy season it had $98.04 \%$ pollen viability followed by FCR test (70\%) and TTC test (62.70\%) (Table 4, Figure 7). For in vitro pollen germination, maximum pollens germinated during rainy season. Brewbaker and Kwack's Medium performed maximum germination with maximum tube length of pollens; among the various concentration of sucrose solution pollen germination and tube length increased as increasing solution concentration (Table 5, Figure 8). In vivo study of pollen germination and tube elongation on stigmatic surface, Alexander's multiple staining method performed better germination and elongation while aniline blue fluorescence test showed only high pollen load (Figure 9). 
Table 4. Pollen viability in different tests under various seasons

\begin{tabular}{|c|c|c|c|}
\hline \multirow{2}{*}{ Viability Test } & \multicolumn{3}{|c|}{ Season } \\
\cline { 2 - 4 } & Winter & Summer & Rainy \\
\hline Alexander test (\%) & 84.32 & 69.35 & 62.04 \\
\hline TTC test (\%) & 40.50 & 18.50 & 70.00 \\
\hline FCR test (\%) & 66.60 & 51.00 & \\
\hline
\end{tabular}

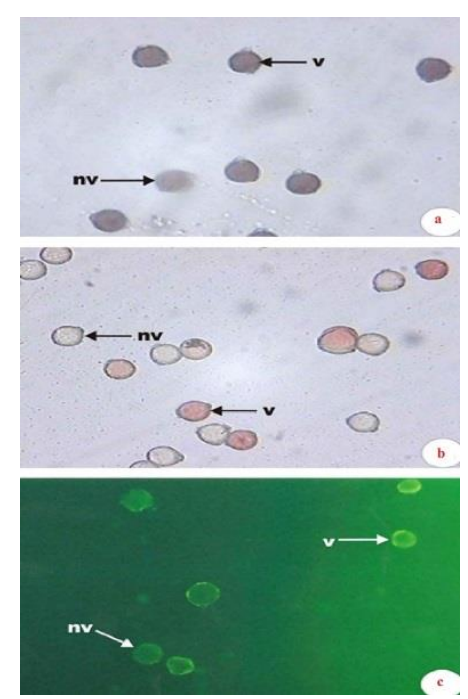

Figure 7. Viable (v) and non-viable (nv) pollens in various tests a. Alexander's stain test; b. TTC test; $\mathbf{c}$. Fluorochromatic reaction (FCR) test

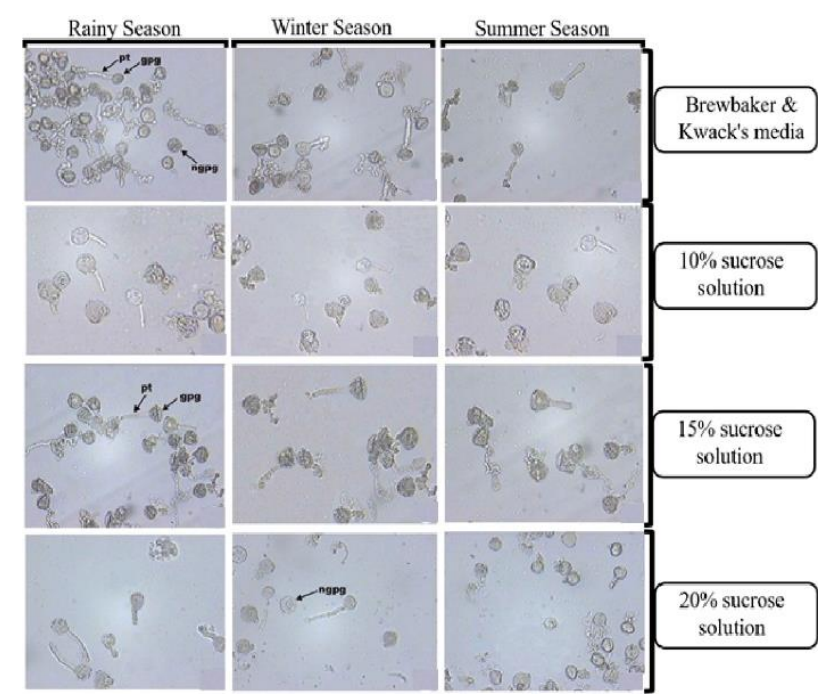

Figure 8. In vitro pollen germination in different media under various seasons

Table 5. In vitro pollen germination in different media under various seasons

\begin{tabular}{|c|c|c|c|c|c|c|c|c|}
\hline \multirow{2}{*}{ Season } & \multirow{2}{*}{$\begin{array}{c}\text { Brewbaker \& Kwack's } \\
\text { Medium }\end{array}$} & \multicolumn{4}{|c|}{ Sucrose solution } \\
\cline { 2 - 9 } & PG $(\%)$ & TL $(\mu \mathrm{m})$ & PG $(\%)$ & TL $(\mu \mathrm{m})$ & PG $(\%)$ & TL $(\mu \mathrm{m})$ & PG $(\%)$ & TL $(\mu \mathrm{m})$ \\
\hline Winter & 57.3 & $125.01 \pm 8.79$ & 32.0 & $50.1 \pm 1.29$ & 48.0 & $51.45 \pm 5.39$ & 53.0 & $109.79 \pm 8.43$ \\
\hline Summer & 52.0 & $118.05 \pm 4.25$ & 30.0 & $49.2 \pm 3.45$ & 45.0 & $51.00 \pm 9.01$ & 50.0 & $105.0 \pm 11.20$ \\
\hline Rainy & 60.0 & $128.30 \pm 7.45$ & 34.0 & $51.6 \pm 7.45$ & 50.0 & $53.30 \pm 7.49$ & 56.0 & $113.33 \pm 7.45$ \\
\hline
\end{tabular}



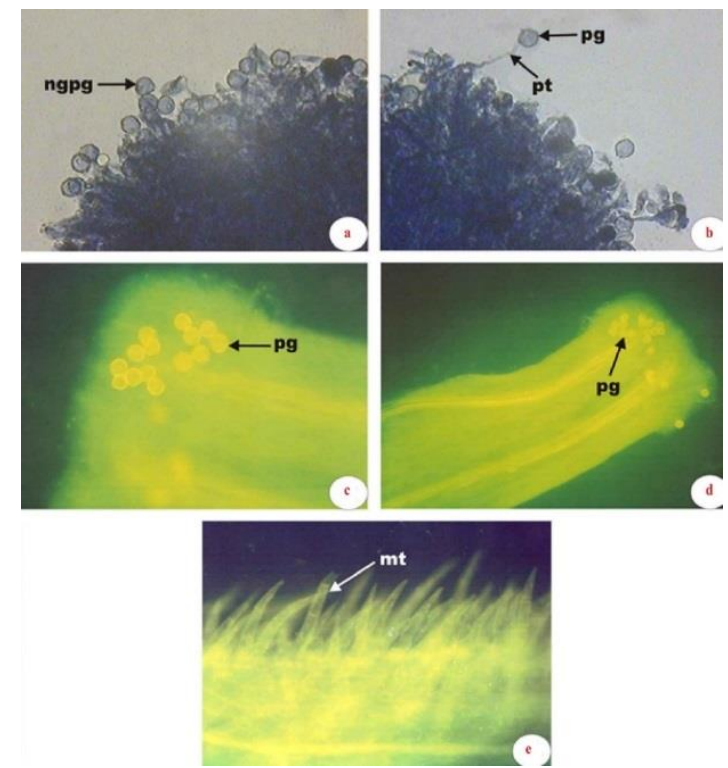

Figure 9. In vivo pollen germination on stigmatic surface $\mathbf{a} \& \mathbf{b}$. Alexander's multiple staining method; $\mathbf{c}$. aniline blue fluorescence method; $\mathbf{d}$. high pollen load on stigmatic surface; e. multicellular trichomes (mt) on stylar surface

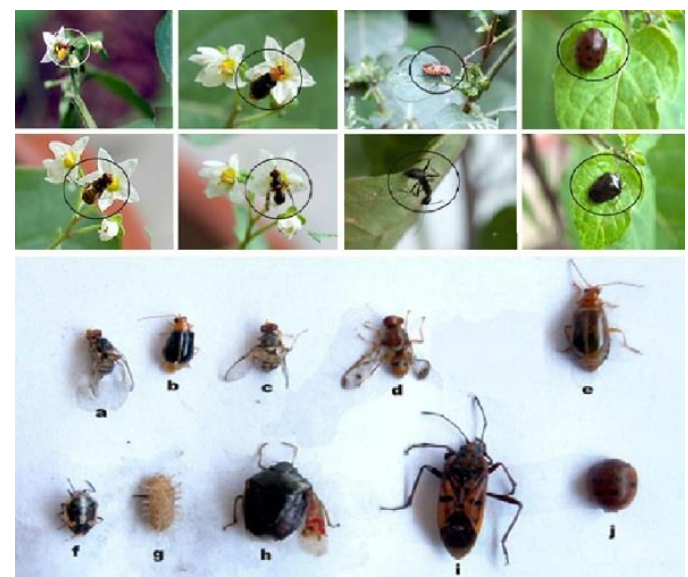

Figure 10. Different pollinators and visitors in S. nigrum plant

In the study of fruit set percentage under different mode of pollinations, open pollination performed a maximum $90 \%$ and self-pollination $80 \%$ while cross-pollination performed $15 \%$ in geitenogamy and $7 \%$ in xenogamy (Table 6). Different pollinators and visitors during this investigation have been shown in Figure 10. Number of fruits and fruit set percentage in different seasons were studied, maximum percentage was recorded during rainy season followed by winter and summer; a maximum $5.88 \%$ and $85 \%$ fruiting and fruit set recorded respectively during rainy season while minimum $3.79 \%$ and $56 \%$ during summer (Table 7 ).

Table 6. Percentage of fruit-set under different mode of pollination

\begin{tabular}{|c|c|c|c|c|}
\hline \multirow{2}{*}{ Mode of pollination } & \multirow{2}{*}{ Open pollination } & \multirow{2}{*}{ Self-pollination } & \multicolumn{2}{|c|}{ Cross-pollination } \\
\cline { 3 - 5 } & 90 & 80 & Geitonogamy & Xenogamy \\
\hline Fruit set $(\%)$ & 90 & 15 & 7 \\
\hline
\end{tabular}


Table 7. Number of fruits and fruit set percentage in different season

\begin{tabular}{|c|c|c|c|}
\hline \multirow{2}{*}{ Parameters } & \multicolumn{3}{|c|}{ Season } \\
\cline { 2 - 4 } & Winter & Summer & $5.88 \pm 1.66$ \\
\hline Fruits/inflorescence & $4.11 \pm 1.93$ & $3.79 \pm 0.06$ & 85.0 \\
\hline Fruit set $(\%)$ & 72.2 & 56.0 & \\
\hline
\end{tabular}

\section{Discussion}

Floral biology considered the study of flower parts which includes tepals, androecium and gynoecium; individually the study of reproductive part is reproductive biology. In this study, anthesis, anther dehiscence and stigmatic receptivity occurred simultaneously in all the seasons; pollens per anther and flower were 700 and 3500 respectively; pollen and ovule ratio were 70:1. Similar observation recorded in Withania somnifera by Jha (2005), mechanism of anther dehiscence, anthers opening and release of pollen grains varies in different plants (Arey and Keating, 1996). Under different climatic conditions the flowers of $S$. nigrum exhibited various interesting polymorphic features, as length and numbers of petals, anthers and pistil. It was interesting to note that all polymorphic features present on single plant as well as different plants during investigation. In normal, flower have five petals, five stamens and one pistil while here some showed polymorphism with four, nine and ten petals; ten stamens and two pistils during various climatic influences. Similar polymorphic observations were recorded in different plants during various previous investigations; as in Tecoma stans (Singh and Chauhan, 1994), Cassia tora (Sharma et al., 2006), Pyrostegia venusta (Singh et al., 2009). Stylar polymorphism recorded in various plants of Solanaceae by many of the studies; as in Solanum ovigerum (Saha and Datta, 2018), S. hirutum, S. melanospermum (Diggle and Miller, 2004). The sexual polymorphisms increase the precision of cross pollination and reduce lost mating opportunities associated with self-interference, especially geitonogamy (Barrett et al., 2000).

In the study of SEM, dorsal surface of sepal shows the presence of procumbent glandular trichomes and stomata, extra floral nectaries in abaxial surface of the corolla and multicellular trichomes on various floral parts; similarly, extra floral necteries were observed on the corolla of Solanum cunninghamii, S. diocum and $S$. tudununggae (Gregory and David, 1985). Pollen morphology is of great significance in taxonomy, phylogeny, palaeobotany, aeropalynology and pollen allergy. Pollen identification on the basis of palynology is based exclusively on pollen morphology (Shivanna, 2003). Gentry (1986) examined the pollens morphology in thirteen genera (Cestrum L., Coeloneurum Radlk., Fabiana Ruiz \& Pav., Goetzea Wydler., Juanulloa Ruiz \& Pav., Markea Rich., Metternichia J.C. Mikan, Nicotiana L., Nierembergia Ruiz \& Pav., Petunia Juss., Rahowardiana D'Arcy, Sclerophylax Miers and Vestia Willd.) and twenty species of cestreae tribe (solanaceae) by using SEM where he observed, majority of the taxa were characterized by tricolporate, monad pollen grains and exine sculpturing in striate, regulate, foveolate, scabrate, echinate and reticulate. In the case of stigma's SEM study, it showed twisted bilobed, presence of small and loosely arranged papillae on the stigmatic surface while stylar surface showed the presence of multicellular trichomes. Similar type of stigmatic characters was reported in Withania somnifera (Kaul et al., 2005), Duranta repens L. (Sharma and Rana, 2009) and Solanum ovigerum (Saha and Datta, 2018).

Pollen viability and germination were maximum during rainy season followed by winter and summer in various tests (Alexander, TTC and FRC). Similar results were obtained in Withania somnifera (Kaul et al., 2005) and Solanum ovigerum (Saha and Datta, 2018). The viability mainly affected by temperature and humidity; many previous studies clearly indicated their effect on pollen viability (Kaul, 1970; Gupta and Nanda, 1973; Chauhan and Kumar, 1980; Jain and Chauhan, 1985). On the other hand, pollen viability is one of the limiting factors that affect seed-formation (Koltunone et al., 1990; Goldberg et al., 1993; Yang and Sundaresan, 2000). In the report of Shivanna and Johri (1985) the pollen germination and tube growth were 
highly sensitive to climatic factors. The pollen germination and growth increased with increasing sugar concentration similar as the study of Tupy (1960).

Pollination is a most important process for plants which creates the initiation of progeny. The attractants (flowers, inflorescence, floral architecture and floral density) and rewards (quantity of pollens and nectar) of $S$. nigrum L., invites a wide variety of insects during different season. Many pollinators or visitors as black ants (Componotus campestris), small bees, bug (Nezara viridala), beetle (Epilachna spp.), Lygaeus sp. and Diabrotica sp. etc. visited on plants. Among all the pollinators; black ant was identified as most efficient pollinator. Pollen grains were observed on the mouth parts, legs and wings of these visitors which create results of pollen load, visitation rate and fruit-set. Fruit-set varies with seasons, maximum occurred during rainy season followed by winter and summer. Autogamy performed higher percentage of fruit-set while other modes have very small percentage. Similarly, Kaul et al. (2005) observed maximum $80-85 \%$ of fruit-set in Withania somnifera by autogamy. Xenogamic cross gave only $2-4 \%$ fruit-set which is similar as in Jatropha gossypifolia $\mathrm{L}$. (Gupta, 2004) and Withania somnifera (Jha, 2005).

\section{Conclusions}

In nutshell, this study confirms the effect of various climates on vegetative as well as floral parts. During different climates flower showed polymorphism as recorded in petals, stamens and pistil. Among various climates rainy season was better for all selected parameters followed by winter, hence, this study concluded that the rainy season provides most suitable climate to the Solanum nigrum L. In this respect, this study might be helpful for the climate related biologist due to huge change in climate day by day.

\section{Authors' Contributions}

Both authors conceived and designed this work. CK conducted experiments and wrote the manuscript. IPS analyzed data and finalizes the draft.

\section{Acknowledgements}

Authors are greatly thankful to All India Institute of Medical Sciences (AIIMS), New Delhi for providing Scanning Electron Microscope (SEM) to this study.

\section{Conflict of Interests}

The authors declare that there are no conflicts of interest related to this article.

\section{References}

Arey WGD, Keating RC (1996). The anther form, function and physiology. Cambridge University, Press.

Barret SCH (1985). Floral trimorphism and monomorphism in island population of Eicchornia paniculata (Pontederiaceae). Biological Journal of the Linnean Society 25:41-60.

Barrett SCH, Jesson LK, Baker AM (2000). The evolution and function of stylar polymorphism in flowering plants. Annals of Botany 85:253-262. 
Brewbaker JL, Kwack BH (1963). The essential role of calcium ion in pollen germination and pollen tube growth. American Journal of Botany 50:859-865.

Chauhan SVS, Kumar R (1980). Effect of temperature on histological and biochemical changes in the anthers of Tecoma stans L. Journal of the Indian Botanical Society 47:71.

De Silva HA, Saparamadu PA, Thabrew MI, Pathmeswaran A, Fonseka MM, De Silva HJ (2003). Liv.52 in alcoholic liver disease: a prospective, controlled trial. Journal of Ethnopharmacology 84:47-50.

Diggl PK, Mille, JS (2004). Architectural effects mimic floral sexual dimorphism in Solanum (Solanaceae). American Journal of Botany 91:2030-2040.

Dutkuner I, Bilir N, Ulusan MD (2008). Influence of growth on reproductive traits and its effect on fertility and gene diversity in a clonal seed orchard of scots pine, Pinus sylvestris L. Journal of Environmental Biology 29:349-352.

Fallah HSM, Heshmat RA, Heydari MR, Abolmaali K (2005). The efficacy of Liv-52 on liver cirrhotic patients: A randomized, double-blind, placebo-controlled first approach. Phytomedicine 12:619-624

Gentry JLJ (1986). Pollen studies in the Cestreae (Solanaceae). In: D’Arcy WG (Ed). Solanaceae: Biology and Systematics. Colombia University Press, New York pp 137-158.

Goldberg RB, Beals TP, Sanders PM (1993). Anther development: basic principles and practical applications. Plant Cell 5:1217-1229.

Gregory JA, David ES (1985). Extrafloral nectries in Solanum, Association for tropical biology and conservation. Biotropica 17:40-45.

Gupta G (2004). Reproductive biology of Jatropha gossypifolia L. M. Phil. Dissertation, Dr. B.R. Ambedkar University, Agra.

Gupta SC, Nanda K (1973). Fibrous endothecium, tapetum and pollen development in Belamcanda chinensis DC. Botanical Gazette 134:125-129.

Holm LG, Plunknett DL, Pancho JV, Herberger JP (1977). Distribution and biology. Solanum nigrum L. University Press of Hawaii, pp 430-434.

Hughes L (2000). Biological consequences of global warming: Is the signal already apparent. Trends in Ecology \& Evolution 15:56-61.

Jain RK, Chauhan SVS (1985). Morphological and biochemical study in environmental sterility in Jacaranda mimosifolia L. incompatibility. Newsletter 17:14-16.

Jha L (2005). Phenology and Reproductive biology of Withania somnifera. M Phill Dissertation, Dr. B. R. Ambedkar University, Agra.

Kaul CL (1970). Investigation into the causes of sterility II. Tabernaemontana ornaria wild. Cytologica 36:370-376.

Kaul MK, Kumar A, Sharma A (2005). Reproductive biology of Withania somnifera (L.) Dunal. Current Science 88:1375-1377.

Kearns CA, Inouye DW (1993). Techniques for pollination Biologist. Niwot, CO: University Press of Colorado p 583.

Koltunone AW, Truettner J, Cox KH, Mallroth M, Goldberg RB (1990). Different tropical and spatial gene expression pattern occurring during anther development. Plant Cell 2:1201-1224.

Lawlor DW (2002). Limitation to photosynthesis in water stressed leaves: stomata vs. metabolism and the role of ATP. Annals of Botany 89:1-15.

Ogg AG, Rogers BS (1989). Taxonomy, distribution, biology and control of black nightshade (Solanum nigrum) and related species in the United States and Canada. Review Weed Science 4:25-58.

Parmesan C (2006). Ecological and evolutionary responses to recent climate change. Annual Review of Ecology, Evolution, and Systematics 37:637-669.

Parmesan C, Yohe G (2003). A globally coherent fingerprint of climate change impacts across natural systems. Nature $421: 37-42$

Raghavan V (2000). Developmental Biology of Flowering Plants. Springer, Verlag, New York.

Root TL, Price JT, Hall KR (2003). Fingerprints of global warming on wild animals and plants. Nature 421:57-60.

Saha M, Datta BK (2018). Reproductive biology of Solanum ovigerum Dunal. Bioscience Discovery 9:155-161.

Sedgley M, Griffin AR (1989). Sexual Reproduction in tree crops. Academic press, Harcourt Brace Jovanovich pub, London p 370.

Sharma D, Rana A (2009). Reproductive Biology of Duranta repens L. (Verbenaceae) in relation to its environment. International Journal of Plant Reproductive Biology 1:5-9.

Sharma SB, Rana A, Chauhan SVS (2006). Reproductive biology of Crataeva religiosa Forst. Current Science 90:716-720. 
Shivanna KR (2003). Pollen Biology and Biotechnology. Oxford and IBH Publication Co. Pvt. Ltd. New Delhi. Shivanna KR, Johri BM (1985). The Angiosperm Pollen Structure and Function. Wiley Eastern Ltd. Publisher, New Delhi.

Shivanna KR, Rangaswamy NS (1992). Pollen biology: A laboratory manual. Narosa publishing house, New Delhi.

Singh J, Chauhan SVS (1994). Floral polymorphism and establishment of SI in Tecoma stans. Journal of Tree Science 13:57-60.

Singh S, Rana A, Chauhan SVS (2009). Impact of environmental changes on the reproductive biology in Pyrostegia venusta Presl. Journal of Environment Biology 30:271-273.

Taiz L, Zeiger E (2003). Plant Physiology. Panama Publishing Corporation ( $5^{\text {th }}$ Edn), New Delhi.

Tupy J (1960). Sugar absorption, callose formation and the growth rate of pollen tubes. Biologia Plantarum 2:169-180.

Walther GR, Post E, Convey P, Menzel A, Parmesan C, Beebee TJC (2002). Ecological responses to recent climate change. Nature 416:389-395.

Yang WC, Sundaresan V (2000). Genetics of gametophyte biogenesis in Arabidopsis. Current Opinion in Plant Biology 3:53-57.

The journal offers free, immediate, and unrestricted access to peer-reviewed research and scholarly work. Users are allowed to read, download, copy, distribute, print, search, or link to the full texts of the articles, or use them for any other lawful purpose, without asking prior permission from the publisher or the author.

License - Articles published in Notulae Scientia Biologicae are Open-Access, distributed under the terms and conditions of the Creative Commons Attribution (CC BY 4.0) License.

(c) Articles by the authors; SHST, Cluj-Napoca, Romania. The journal allows the author(s) to hold the copyright/to retain publishing rights without restriction. 